Care: Jurnal Ilmiah Ilmu Kesehatan Vol .7, No.3, 2019, hal 138-148

Tersedia online di https://jurnal.unitri.ac.id/index.php/care

ISSN 2527-8487 (online)

ISSN 2089-4503 (cetak)

\title{
EFEKTIVITAS NATURAL FACE MASK DALAM MENINGKATKAN KELEMBABAN KULIT WAJAH
}

\author{
Swaidatul Masluhiya AF ${ }^{1)}$, Hasminar Rachman Fidiastuti ${ }^{2)}$ \\ ${ }^{1)}$ Dosen Program Studi Ilmu Keperawatan Fakultas Ilmu Kesehatan \\ Universitas Tribhuwana Tunggadewi Malang \\ ${ }^{2)}$ Dosen Program Studi Biologi Fakultas Ilmu Pendidikan \\ Universitas Tribhuwana Tunggadewi Malang \\ E-mail: swaee.af@gmail.com; swaidha@yahoo.com
}

\begin{abstract}
This study aimed to determine the effect of using natural masks to moisturize dry skin. This natural mask was made of ingredients that are safe to use and based on special formulations which include; bengkoang powder (2 grams), chocolate powder (1 gram), black cumin oil $(0.6 \mathrm{ml})$, and honey $(5 \mathrm{ml})$. This formulation was made so that the resultied mask formed paste stucture that can be directly applied. Masks were given to ten probandal women who have dry skin types and are 30-40 years old. Masks were used twice / week for six weeks (12 times usage). The instrument used to measure the moisture level of facial skin was a skin analyzer (HL-611) by directly attaching it to the face area and the results can be seen after 4-5 seconds. The data were analysed using ANOVA test 95\% confidence interval and significance test using SPSS 15 for windows. The results showed that skin moisture values increased around 3.9\% within 6 weeks of use, with a $0.8 \%$ increase at week 2, at week 4 there was an increase of 1.65\% and at week 6 there was an increase in skin moisture by 1.4\%. The moisture value of the skin on the face area (forehead, nose, chin, cheeks) showed no significant difference with almost the same value of humidity. It is recommended for dry skin types to use a face mask that contains oil as a skin lubricant and to protect water evaporation from the skin. It is necessary to do further testing on this natural mask so that safety on the skin can be guaranteed. It needs to be done so that the final product obtained meets the face mask safety quality standards set by the government.
\end{abstract}

Keywords: Bengkuang; cocoa; black cumin; boney; natural mask.

\begin{abstract}
ABSTRAK
Tujuan penelitian ini adalah untuk mengetahui efektivitas natural face mask dalam meningkatkan kelembaban kulit wajah. Natural face mask ini dibuat dari bahan-bahan yang aman digunakan dan dibuat berdasarkan formulasi khusus yang meliputi; bubuk bengkoang ( 2 gram), bubuk cokelat (1 gram), minyak jintan hitam $(0.6 \mathrm{ml})$, dan madu $(5 \mathrm{ml})$. Formulasi ini dibuat agar masker yang dihasilkan dapat membentuk struktur seperti krim yang dapat langsung digunakan. Masker diberikan pada sepuluh probandus wanita yang memiliki jenis kulit kering dan berusia 30-40 tahun. Masker digunakan dua kali/minggu selama enam minggu (12 kali pemakaian). Instrumen yang digunakan untuk mengukur tingkat kelembaban kulit wajah
\end{abstract}

Cara mengutip: Masluhiya AF, Swaidatul., \& Fidiastuti, H. Rachman. (2019). Efektivitas Natural Face Mask dalam Meningkatkan Kelembaban Kulit Wajah. Care:Jurnal Ilmiah Ilmu Kesehatan, 7(3), 138-148 
adalah skin analyzer (HL-611) dengan cara langsung ditempelkan pada area wajah dan hasilnya dapat terlihat setelah 4-5 detik. Analisa data dengan uji ANOVA selang kepercayaan 95\% dan uji signifikansi menggunakan SPSS 15 for windows. Hasil penelitian menunjukkan nilai kelembaban kulit meningkat sekitar $3.9 \%$ dalam waktu 6 minggu pemakaian, dengan peningkatan $0.8 \%$ pada minggu ke-2, pada minggu ke-4 terjadi peningkatan sebanyak $1.65 \%$ dan pada minggu ke-6 terjadi peningkatan kelembaban kulit sebanyak 1.4\%. Nilai kelembaban kulit pada area wajah (dahi, hidung, dagu, pipi) menunjukkan tidak ada perbedaan yang signifikan dengan nilai kelembaban yang hampir sama. Disarankan bagi jenis kulit kering agar menggunakan masker wajah yang memiliki kandungan minyak sebagai pelumas kulit dan untuk melindungi evaporasi air dari kulit. Perlu dilakukan uji lanjutan pada masker alami ini agar keamanan kulit dapat terjamin. Hal ini dilakukan agar produk akhir yang didapatkan memenuhi standar mutu keamanan masker wajah yang ditetapkan pemerintah.

Kata Kunci: Bengkoang; cokelat; jintan hitam; madu; masker alami.

\section{PENDAHULUAN}

Industri kosmetik yang terus berkembang saat ini menghasilkan beragam produk kosmetik dengan berbagai keunggulan, baik dari segi merk, kandungan, jenis, harga, maupun komposisi bahan dalam produk tersebut. Salahsatu produk kosmetik yang banyak diminati adalah masker wajah. Masker wajah ini memiliki berbagai fungsi, seperti dapat mengurangi kerutan, menghilangkan bekas jerawat, mencerahkan, hingga dapat melembabkan kulit wajah. Fakta ini menyebabkan konsumen merasa kesulitan dalam memilih produk masker yang sesuai dengan kondisi kulit, terutama yang kurang paham mengenai masker wajah. Berkembangnya media sosial saat ini dapat memudahkan konsumen dalam mendapatkan berbagai produk kosmetik seperti masker wajah dengan berbagai merk, akan tetapi jika konsumen salah memilih maka menimbulkan permasalahan yang lebih berat pada kulit (Adsense, 2011).
Berdasarkan hasil evaluasi market yang telat dilakukan menunjukkan bahwa beberapa masker wajah yang dijual bebas dipasaran memiliki kandungan bahan berbahaya, dimana pencampuran bahanbahan tersebut harus memenuhi ketentuan pembuatan kosmetika, diantaranya sulfur dan resorsin yang dapat merusak struktur dan faal sel kulit, sehingga tidak sepenuhnya aman bagi kulit wajah.

Penelitian ini mencoba untuk membuat masker wajah yang memformulasikan bahan alami sehingga aman untuk kulit wajah terutama jenis kulit kering. Masker alami ini dibuat dalam bentuk krim yang dapat diaplikasikan langsung ke kulit wajah. Keistimewaan dari formulasi masker wajah alamai ini diantaranya tidak mencampurkan bahan-bahan tambahan seperti pengharum, pengawet, dan pewarna buatan. Masker alami ini dibuat secara tradisional dengan mencampurkan bahan alami lain seperti bubuk bengkoang, cokelat bubuk, madu, dan minyak jintan hitam. Masker alami ini 
tidak mengering dan tidak mengeras jika digunakan pada kulit wajah.

Bengkoang dipilih karena mudah didapatkan dan harganya relatif murah, selain itu kandungan vitamin C dalam bengkoang bermanfaat dalam pembentukan kolagen dan proses pigmentasi, sedangkan kandungan vitamin B1 dalam bengkoang berfungsi untuk mencerahkan, menghaluskan kulit, dan mengurangi kekeringan (Anneahira, 2011). Bahan lain yang digunakan adalah bubuk cokelat dengan kandungan vitamin A untuk mengurangi kekeringan kulit. Cokelat bubuk dipilih karena memiliki kandungan polifenol sehingga tidak mudah tengik. Menurut Lee (2003) cokelat bubuk mengandung antioksidan lebih tinggi dua kali lipat daripada kandungan antioksidan dalam anggur merah dan lebih dari tiga kali kandungan antioksidan teh hijau

Minyak jintan hitam dipilih karena memiliki banyak unsur kimia alami yang diperlukan oleh kulit seperti kandungan thymoquinon yang berfungsi untuk aktivitas antioksidatif dan antiinflamasi (Zaher, 2008), selain itu kandungan minyak Jintan hitam seperti asam linoleat dan linolenat (asam lemak esensial tak jenuh) yang fungsinya untuk menunda proses penuaan dan meremajakan sel-sel kulit (Childiest, 2010). Tingginya kandungan asam lemak tak jenuh dalam minyak jintan hitam menyebabkan tahan terhadap oksidasi.

Madu juga dijadikan bahan dalam penelitian ini karena sifatnya yang berfungsi sebagai bumectants untuk menarik air dari udara sekitar dan memperhankan air dalam kulit, sehingga kulit tidak mengalami dehidrasi dan kelembaban kulit tetap terjaga. Menurut Squidoo (2012) madu dapat menghambat proses aging dan mencegah keriput sehingga cocok digunakan pada semua jenis kulit.

Penduduk Indonesia yang beriklim tropis rentan mengalami berbagai masalah kulit seperti kulit kering karena berkurangnya kadar kelembaban kulit. Definisi kulit kering atau dry skin adalah kondisi yang menggambarkan hilangnya atau berkurangnya kadar kelembaban di stratum corneum (SC). Menurut Wijaya (2011) air merupakan bahan utama dalam kelenturan dan kelembaban kulit. Pada proses penuaan kemampuan SC mengikat air berkurang, sehingga kulit tampak mengkilat, berkerut kering dan keras. Faktor yang mempengaruhi kelembaban kulit diantaranya kecepatan cairan dari lapisan bawah mencapai SC, kecepatan penguapan cairan, dan kemampuan SC untuk menahan cairan (Partogi, 2008).

Berdasarkan hasil observasi dan wawancara pada tanggal 15 Juni 2018 pada 10 wanita yang berusia 30-40 tahun dan tergolong memiliki kulit kering, di karenakan kegiatan yang banyak melakukan aktifitas di luar 
ruangan, tidak menggunakan sunblock, dan tinggal di daerah industri (panas), sehingga kulit wajah menjadi kering, bersisik, kasar, kusam dan terasa kaku. Hal ini merupakan masalah yang cukup mengganggu dan dapat mengurangi rasa percaya diri. Upaya untuk mengatasi masalah tersebut salah satunya dengan menggunakan masker wajah alami yang dapat menjaga, mengembalikan dan meningkatkan kelembaban kulit wajah. Penelitian ini penting dilakukan untuk mengembalikan kelembaban kulit wajah dan mengangkat manfaat bahan-bahan alami sebagai bahan masker wajah yang aman untuk jenis kulit kering. Pentingnya penggunaan masker alami inilah yang menjadi latarbelakang pembuatan masker alami agar penggunaan bahan kimia berbahaya yang dapat merusak kulit wajah dapat dicegah dan dikurangi.

\section{METODE PENELITIAN}

\section{Waktu dan Tempat Penelitian}

Penelitian ini dilaksanakan pada tanggal 2 Juli 2018 hingga 18 Agustus 2018 di Dusun Lawatan Desa Kalirejo Kecamatan Sukorejo Kabupaten Pasuruan Jawa Timur.

\section{Bahan pembuatan masker wajah alami}

Bahan-bahan yang dipilih dalam penelitian ini diperoleh dari pemasok, yang meliputi bubuk bengkoang, cokelat bubuk (merk dagang Van Houten), minyak jintan hitam (merk dagang An-Naafi), dan madu (nektar bunga randu).
Formulasi Masker Wajah

Masker alami dibuat dengan mencampurkan empat bahan (bubuk bengkoang, cokelat bubuk, minyak jintan hitam, dan madu) sehingga menghasilkan masker dengan bentuk pasta yang dapat langsung digunakan. Bahan-bahan yang digunakan adalah bubuk bengkoang (2 gram), bubuk cokelat (1 gram), minyak jintan hitam $(0.6 \mathrm{ml})$, dan madu $(5 \mathrm{ml})$. Bahan di letakkan di atas plate yang di lapisi dengan wrapplastic $(13 \times 11 \mathrm{~cm})$, selanjutnya bahan tersebut di aduk dengan spatula sehingga semua bahan tercampur rata dan homogen ( \pm 7 menit). Setelah homogen, disatukan setiap sisi dari wrapplastic (ditutup) dan di lubangi bagian bawah plastik untuk dimasukkan dalam pot krim (ukuran 12,5 gram). Masker di aduk kembali dengan spatula selama 3 menit setelah masker dimasukkan dalam pot krim ggar lebih homogen. Setelah selesai, masker dapat disimpan pada suhu ruang.

\section{Uji Iritasi Kulit}

Uji iritasi dilakukan sebelum penggunaan masker ke wajah yang bertujuan untuk mengetahui keamanan penggunaan masker pada kulit wajah dengan cara dioleskan pada kulit dibelakang telinga dan pada punggung tangan probandus selama 20-30 menit, selanjutnya masker dihapus dan diamati hasilnya. Jika tidak menimbulkan kemerahan ataupun rasa gatal pada probandus, maka masker aman digunakan 
untuk kulit wajah.

\section{Kriteria Inklusi Probandus}

Kriteria inklusi probandus pada penelitian ini adalah wanita yang berusia 30-40 tahun, tergolong jenis kulit kering, selama 3 bulan terakhir tidak melakukan perawatan kulit seperti facial, peeling, dan menggunakan produk masker lain, sudah menikah serta tidak sensitif dengan bahan-bahan yang digunakan untuk masker wajah.

\section{Cara Penggunaan Masker Wajah}

Cara penggunaan masker wajah dalam penelitian ini tidak berbeda dengan penggunaan masker wajah pada umumnya, yaitu:

1) Membersihkan wajah (cuci muka) menggunakan sabun bayi $(\mathrm{pH}$ netral)

2) Dikeringkan dengan tissue

3) Oleskan masker pada wajah menggunakan kuas (kecuali area mata dan sekitar bibir)

4) Dibiarkan selama 30-60 menit

5) Dibilas menggunakan air hangat sampai bersih.

Penggunaan masker pada probandus sebaiknya pada malam hari sebelum tidur. Masker digunakan dua kali per minggu sampai 12 kali pemakaian masker (selama 6 minggu) selanjutnya dilakukan pengambilan data.

Kontrol

Setiap probandus dilihat jenis kulitnya dengan mengamati ciri-ciri dan karakteristik yang terlihat, selanjutnya di ukur nilai kelembaban kulit. Instrumen untuk mengukur kelembaban kulit wajah adalah skin analyzer HL-611 (Beautistyle International Corporation) dengan cara langsung ditempelkan pada kulit wajah dan nilai kelembaban akan terlihat pada alat skin analyzer HL-611 setelah 4-5 detik (Gambar 1). Nilai ini digunakan sebagai data kontrol (minggu ke-0).

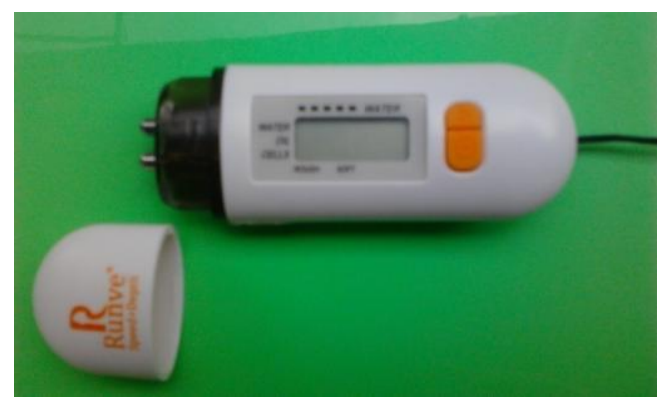

Gambar 1. skin analyzer HL-611 (Beautistyle International Corporation)

\section{Perlakuan}

Masing-masing probandus diamati jenis kulitnya dengan mengamati ciri-ciri dan karakteristik yang terlihat, selanjutnya di ukur nilai kelembaban kulit. Data diperoleh setelah probandus menggunakan masker wajah sebanyak 4 kali. Cara pengambilan data dimulai dengan membersihkan wajah terlebih dahulu menggunakan sabun yang disediakan peneliti (cuci muka), selanjutnya dikeringkan dengan tissue. Pengukuran kelembaban kulit wajah dilakukan setelah 20-30 menit dari cuci muka.

\section{Pengamatan (pengambilan data)}

Area kulit wajah bagian dahi, hidung, dagu, dan pipi diukur nilai kelembabannya 
dengan skin analyzer (HL-611). Nilai kelembaban kulit yang tertera pada layar skin analyzer dalam satuan persentase (\%) menunjukkan jenis kulit yang dimiliki probandus (Tabel 1). Minggu ke-0 (Kontrol) dibandingkan dengan hasil dari setiap pengamatan yang dilakukan pada minggu ke-2, 4, dan 6 kemudian ditentukan efektivitas masker wajah untuk melembabkan. Efektivitas masker wajah ini juga diketahui dari kuisioner yang diisi probandus di akhir penelitian.

Tabel 1. Kriteria jenis kulit berdasarkan kandungan air di kulit wajah yang tertera pada skin analyzer HL-611 (Beautistyle International Corporation) adalah:

\begin{tabular}{cc}
\hline Kandungan air & Jenis kulit \\
\hline$<=33 \%$ & Sangat kering \\
$34-37 \%$ & Kulit kering \\
$38-42 \%$ & Kulit normal \\
$43-46 \%$ & Kulit lembab \\
$>=47 \%$ & Sangat lembab \\
\hline
\end{tabular}

\section{Analisis Data Kelembaban Kulit}

Data kelembaban kulit yang diperoleh pada setiap minggu pengamatan (ke-0, 2, 4, dan 6) dianalisis dengan uji ANOVA. Area perlakuan meliputi dahi, hidung, dagu, dan pipi. Waktu (minggu ke-) sebagai kelompok perlakuan dan probandus sebagai ulangan.

\section{HASIL}

Efektivitas natural face mask untuk melembabkan kulit wajah diformulasikan dengan empat bahan yang menghasilkan struktur seperti krim yang dapat langsung dioleskan pada wajah tanpa memerlukan air ataupun campuran lain didalamanya. Cara membuat masker dimulai dari mencampur bahan dengan tekstur bubuk, bahan yang bertekstur minyak, dan terakhir dicampurkan bahan yang berfungsi sebagai pelarut (pengkelat). Berat masker dari hasil formulasi ini adalah 10.5 gram, selanjutnya masker disimpan pada suhu ruang. Masker alami ini tidak dapat mengering selama pemakaian karena terdapat campuran minyak dalam formulasinya. Selain itu, kandungan air yang terdapat pada bahan yang digunakan tidak mudah menguap sehingga masker tidak dapat mengering selama pemakaian.

Berdasarkan data kelembaban kulit wajah, dilakukan pengujian nilai kelembaban kulit yang paling tinggi (area yang paling lembab) pada setiap area wajah serta diamati peningkatan nilai kelembaban kulit pada minggu ke-0, 2, 4, dan 6. Pengaruh penggunaan masker wajah terhadap kelembaban kulit dianalisis menggunakan uji ANOVA. Berdasarkan hasil perhitungan statistika diketahui bahwa pada sumber keragaman (SK) area wajah, didapatkan nilai F-hitung lebih kecil daripada F-tabel 5\% $(1.915<2.664)$ dan dari perbandingan antara nilai signifikansi dengan $a=0.05$ diketahui $0.129>0.05$, artinya tidak ada perbedaan yang signifikan 
pada nilai kelembaban kulit wajah (dahi, hidung, dagu, dan pipi). Hasil pengukuran dengan skin analyzer HL-611 menunjukkan bahwa rerata kelembaban kulit berkisar antara 32.975\%-36.85\% (Gambar 2) yang termasuk ke dalam jenis kulit kering (3437\%) (Tabel 1).

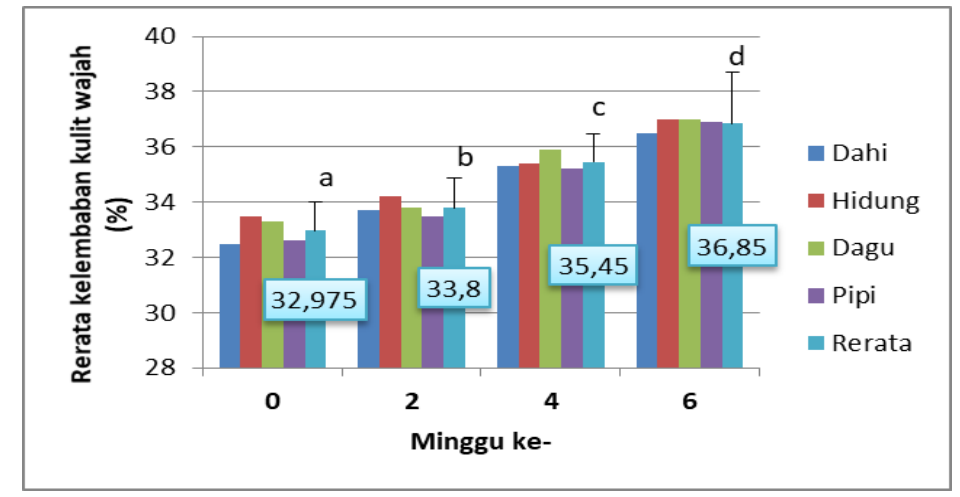

Gambar 2. Rerata nilai kelembaban kulit wajah pada setiap pengamatan.

Nilai kelembaban kulit wajah mulai meningkat dari minggu ke-2 pengamatan. Pada sumber keragaman (SK) waktu (minggu ke-), didapatkan nilai F-hitung lebih besar dari F-tabel 5\% (71.668 > 2.664) dan dari perbandingan antara nilai signifikansi dengan $a=0.05$ menunjukkan nilai signifikansi lebih kecil dari $a=0.05$ $(0.000<0.05)$. Berdasarkan hasil tersebut dapat disimpulkan bahwa ada perbedaan yang signifikan pada tingkat kelembaban kulit wajah disetiap minggu pengamatan selama 6 minggu pengamatan.

Berdasarkan Gambar 2 diketahui bahwa rerata kelembaban kulit wajah pada minggu ke-0 berbeda nyata dengan rerata kelembaban kulit wajah pada minggu ke-2, artinya peningkatan kelembaban sudah terlihat sejak penggunaan masker wajah pada minggu ke-2. Peningkatan kelembaban kulit yang signifikan juga terjadi pada penggunaan masker wajah minggu ke-4 dan ke-6 (nilai kelembaban tertinggi dengan rerata $36.85 \%$ ).

\section{PEMBAHASAN}

Hasil penelitian menunjukkan bahwa masker wajah ini jika dioleskan pada kulit wajah tidak dapat mengering karena terdapat campuran minyak dalam formulasinya. Masker jenis ini sangat sesuai digunakan untuk kulit kering, dimana kandungan bahan aktif didalamnya dapat bekerja sangat baik dan efisien sehingga dapat meningkatkan nilai kelembaban kulit dengan cepat. Menurut Kusantati (2008) masker wajah yang mengandung minyak memiliki keuntungan lebih efektif dalam mengangkat kotoran sisa make-up di wajah yang larut dalam minyak dan tidak larut dalam air, dapat mengurangi kulit kering dan pecah-pecah, sedangkan kelemahan 
produk yang mengandung minyak adalah air yang tertinggal di permukaan kulit akan sulit menguap dan sisa make-up yang larut dalam air akan sulit dibersihkan dengan minyak.

Berdasarkan Gambar 2 menunjukkan kelembaban kulit dibagian dahi, hidung, dagu, dan pipi relatif sama (tidak berbeda signifikan). Hal ini karena lapisan kulit di stratum corneum ketebalannya relatif sama, sehingga menimbulkan reaksi yang sama pada saat pemberian masker wajah. Menurut Simanjuntak (2005) perbedaan ketebalan kulit dibagian tubuh disebabkan oleh perbedaan ketebalan stratum corneum, sehingga jumlah bahan aktif yang diabsorpsi untuk satu molekul yang sama akan menunjukkan hasil yang berbeda tergantung pada struktur anatomi di tempat pengolesan masker wajah. Ketebalan epidermis di bagian tubuh memang berbeda, dimana ketebalan paling tingggi $(1 \mathrm{~mm})$ pada telapak tangan dan telapak kaki sedangkan yang paling tipis adalah bagian kelopak mata, pipi, dahi dan perut (0.1 mm)(Kusantati, 2008). Area pemakaian kosmetik topikal akan mempengaruhi absorbsi bahan aktif masker, jika kulit dengan lapisan tanduk yang tebal, maka absorbsi yang terjadi akan lebih lama. Selain itu, efektivitas kosmetik topikal dipengaruhi oleh pilihan dan konsentrasi bahan, bahan dasar kosmetik, usia dan tingkat hidrasi kulit (Achyar,
1986).

Menurut Achyar (1986) pemakaian kosmetik topikal (masker wajah) akan optimal apabila bahan aktif dapat diabsorpsi oleh kulit minimal sebagian dari kandungan bahan aktif yang ada. Hal ini karena efektivitas masker dipengaruhi oleh frekuensi pemakaian masker wajah. Semakin tinggi frekuensi pemakaian masker wajah, maka semakin efektif bahan masker masuk kelapisan kulit wajah (jumlah bahan aktif yang diabsorbsi ke kulit lebih banyak) sehingga dapat meningkatkan kelembaban kulit wajah secara signifikan. Menurut (Masluhiya AF, Swaidatul., Widodo., \& Widyarti, 2016) frekuensi pemakaian masker wajah untuk dry skin adalah dua kali pemakaian per minggu untuk meningkatkan nilai kelembaban kulit wajah. Masker wajah ini dapat meningkatkan nilai kelembaban kulit $3.9 \%$ dalam waktu 6 minggu pemakaian (2 kali/minggu), dengan peningkatan $0.8 \%$ pada minggu ke-2, pada minggu ke-4 terjadi peningkatan sebanyak $1.65 \%$ dan pada minggu ke-6 terjadi peningkatan kelembaban kulit sebanyak 1.4\%. Masker wajah sebaiknya digunakan pada malam hari karena pada malam hari kulit mengalami regenerasi sehingga dapat melunakkan sel kulit mati dan mencegah hilangnya kelembaban kulit sepanjang malam dimana kulit tidak mengalami kekeringan akibat regenerasi di pagi hari 
(Bentley, 2006).

Bubuk bengkoang digunakan sebagai bahan masker karena memiliki kandungan vitamin $\mathrm{C}$, vitamin $\mathrm{E}$, dan zinc yang berfungsi sebagai antioksidan. Kombinasi beberapa antioksidan dapat menunjukkan efek sinergis untuk mencegah kerusakan kulit yang disebabkan oleh radikal bebas (Wilkinson, J.B. \& Moore, 1982), selain itu vitamin $\mathrm{C}$ berfungsi untuk memelihara kolagen. Pada cokelat bubuk terdapat kandungan vitamin A yang berguna untuk mengurangi kekeringan pada kulit (Fountain, 2011) Kandungan vitamin C dan vitamin A yang digunakan dalam produk topikal harus sesuai kebutuhan dan dilihat permasalahan yang terjadi terlebihdahulu. Permasalahan kulit seperti kerutan, kulit kering, dehidrasi, dan munculnya jerawat, disarankan memakai produk yang mengandung vitamin A. Pernyataan ini didukung oleh Agnes (2011) yang mengatakan bahwa dalam waktu dua minggu, pemakaian produk yang mengandung asam glikolat dan vitamin A dapat meningkatkan kelembaban kulit sekitar 50\%. Selain itu, pemakaian masker dalam waktu tiga bulan dapat mengendalikan kerutan halus sekitar 85\%.

Berdasarkan hasil posttest diketahui bahwa terdapat perbedaan yang dirasakan oleh setiap probandus setelah menggunakan masker wajah alami ini, dimana kulit probandus dirasakan lebih kenyal, lembab dan tidak terlalu berminyak. Kulit probandus terasa nyaman dan tidak mengalami iritasi pada saat menggunakan masker serta kulit menjadi lebih halus dan lebih kencang. Masker alami ini sangat membantu probandus dalam meningkatkan kelembaban kulit wajah. Selain itu, hasil kuisioner juga menunjukkan bahwa 100\% kulit probandus kembali kering setelah tidak lagi menggunakan masker wajah. Masker wajah berfungsi untuk membantu mempertahankan dan menjaga kelembaban kulit wajah, sehingga ketika penggunaan masker dihentikan maka kulit akan kembali kering. Menurut Wasitaatmadja (1997) kulit memiliki Natural Moisturizing Factor (NMF) yang termasuk barier lemak pada lapisan stratum corneum sehingga kulit bisa terlindung dari berbagai faktor yang menyebabkan kering secara alamiah. Pada keadaan tertentu NMF pada kulit tidak mencukupi, sehingga diperlukan perlindungan non alamiah yang memiliki fungsi sama dengan NMF, yaitu dengan memberikan kosmetika pelembab kulit atau dengan penggunaan kosmetik topikal lain seperti penggunaan masker wajah. Diduga setelah probandus tidak lagi menggunakan masker wajah alami ini, tejadi penurunan kadar NMF yang menyebabkan Trans Epidermal Water Loss (TEWL) meningkat sehingga kulit menjadi kering. 


\section{KESIMPULAN}

Efektivitas penggunaan masker wajah alami untuk meningkatkan nilai kelembaban kulit wajah sudah terlihat sejak minggu pertama pengambilan data. Peningkatan kelembaban kulit yang signifikan terjadi pada minggu ke-4 dan ke6. Masker wajah ini dapat meningkatkan kelembaban kulit sekitar 3.9\% dalam waktu 6 minggu pemakaian, dengan peningkatan $0.8 \%$ pada minggu ke-2, pada minggu ke-4 terjadi peningkatan sebanyak $1.65 \%$ dan pada minggu ke-6 terjadi peningkatan kelembaban kulit sebanyak 1.4\%. Penggunaan masker pada minggu ke-6 menunjukkan pengaruh yang paling tinggi terhadap kelembaban kulit wajah dengan nilai rerata sebesar $36,85 \%$, sedangkan untuk nilai kelembaban kulit wajah di bagian dahi, hidung, dagu, dan pipi tidak terdapat perbedaan yang signifikan.

\section{SARAN}

Berdasarkan hasil penelitian yang diperoleh, maka peneliti memberikan saran dengan harapan dapat bermanfaat dalam upaya menjaga kelembaban dan kekencangan kulit. Perawatan kulit wajah yang tergolong kering memiliki prinsip harus mempertahankan lemak kulit yang ada dengan menjaga kelembaban kulit dan menjauhi kandungan zat aktif bahan yang dapat memicu iritasi kulit. Disarankan memilih produk masker wajah yang mengandung minyak yang berfungsi untuk melindungi evaporasi air dari kulit. Perlu dilakukan uji lanjutan seperti uji masa berlakunya masker (expired) agar keamanan kulit dapat terjamin.

\section{REFERENSI}

Achyar, L. Y. (1986). Dasar-dasar kosmetologi kedokteran. Retrieved from http://www.kalbe.co.id/files/cdk/fil es/cdk_041_kosmetika.pdf $\% 22$ http://www.kalbe.co.id/files/cdk/fil es/cdk_041_kosmetika.pdf

Adsense. (2011). Rahasia Resep Cantik Ala Indonesia. Retrieved July 20, 2017, from http://www.smartnewz.info.html Agnes. (2011). Efek Diet Terhadap Kulit. Retrieved from http://www.danes.co.id/artikel3b.ht $\mathrm{ml}$

Anneahira. (2011). Manfaat Bengkoang. Retrieved July 20, 2017, from http://www.anneahira.com

Bentley, V. (2006). Siasat Jitu Awet Muda. Jakarta: Erlangga.

Childiest. (2010). Jintan Hitam dipercaya berasal dari. Retrieved July 20, 2017, from http://www.childiest.co.tv/.html

Fountain. (2011). Cokelat nikmat bermanfaat.

Kusantati, H. P. (2008). Tata Kecantikan Kulit Jilid I. Jakarta: Direktorat Pembinaan Sekolah Menengah Kejuruan.

Lee, K. K. (2003). Cocoa has more phenolic phytochemicals and a higher antioxidant capacity than teas and red wine. J. Agric. Food Chem, 7292-5.

Masluhiya AF, Swaidatul., Widodo., \& Widyarti, S. . (2016). Formulasi Masker Alami Berbahan Dasar Bengkoang Dan Jintan Hitam Untuk Mengurangi Kerutan Pada Kulit Wajah. CARE, 4(2), 22-35. Retrieved 
from

https://jurnal.unitri.ac.id/index.php/

care/article/view/466/461

Partogi, D. (2008). Kulit kering. Retrieved

July 20, 2017, from

http://repository.usu.ac.id/bitstream. pdf.txt.

Simanjuntak, M. (2005). Biofarmasi sediaan yang diberikan melalui kulit. Retrieved from

repository.usu.ac.id/bitstream.pdf.

Squidoo. (2012). Madu banyak

mengandung khasiat bagi manusia.

Retrieved July 20, 2017, from

http://www.squidoo.com/khasiat-

madu

Wasitaatmadja, S. (1997). Penuntun Ilmu

Kosmetika Medik. Jakarta: UI Press.

Wijaya. (2011). Kulit Kering dan

Permasalahannya. Retrieved July 20, 2017, from

http://wijayaskincare.com/artikel.ht

$\mathrm{ml}$

Wilkinson, J.B. \& Moore, R. . (1982).

Harry's Cosmeticology (7th editio). New

York: Chemical Publishing Company.

Zaher, K. S. (2008). Observations on the Biological Effects of Black Cumin Seed (Nigella sativa) and Green Tea (Camellia sinensis). Tanpa Kota: Tanpa Penerbit. 